\title{
IN VITRO ORGANOGENESIS OPTIMIZATION AND PLANTLET REGENERATION IN Citrus sinensis AND C. limonia
}

\author{
Weliton Antonio Bastos de Almeida ${ }^{1,2,5}$; Francisco de Assis Alves Mourão Filho ${ }^{3,6 *}$; Beatriz \\ Madalena Januzzi Mendes ${ }^{4,6}$; Adriana Pinheiro Martinelli Rodriguez ${ }^{4,6}$ \\ ${ }^{1}$ Depto. de Fitotecnia - UFBA/AGR, C.P. 32 - CEP: 44380-000 - Cruz das Almas - BA. \\ ${ }_{3}^{2}$ Pós Graduando em Produção Vegetal - USP/ESALQ. \\ ${ }^{3}$ Depto. de Produção Vegetal - USP/ESALQ, C.P. 9 - CEP: 13418-900 - Piracicaba - SP, Brasil. \\ ${ }_{5}^{4}$ Lab. de Biotecnologia Vegetal - USP/CENA, C.P. 96 - CEP: 13400-970 - Piracicaba - SP, Brasil. \\ ${ }^{5}$ CAPES/PICDT Fellow. \\ ${ }^{6} \mathrm{CNPq}$ Fellow. \\ *Corresponding author <famourao@esalq.usp.br>
}

\begin{abstract}
Exogenous genes can be introduced in plants by genetic transformation techniques. However, an efficient tissue culture system with high rates of plant recovery is necessary for gene introduction. This work aimed to define organogenesis and plant regeneration protocols for sweet orange varieties Natal, Valencia and Hamlin (Citrus sinensis L. Osbeck) and Rangpur lime (Citrus limonia L. Osbeck) which can be used in plant transformation experiments. Seeds of which teguments were removed, were germinated in vitro and maintained in the dark for three weeks, followed by one week at 16-h photoperiod $\left(40 \mu \mathrm{mol} \mathrm{m}^{-2} \mathrm{~s}^{-1}\right)$ and $27 \pm$ $2^{\circ} \mathrm{C}$. Organogenesis induction was done by introducing epicotyl segments in MT medium with $25 \mathrm{~g} \mathrm{~L}^{-1}$ sucrose and different BAP concentrations. After adventitious bud growth, the shoots were transferred to MT medium with either NAA or IBA $\left(1 \mathrm{mg} \mathrm{L}^{-1}\right)$, or absence of auxin, for rooting. The best results were obtained with 1 $\mathrm{mg} \mathrm{L}^{-1} \mathrm{BAP}$ for bud induction and $1 \mathrm{mg} \mathrm{L}^{-1}$ IBA for rooting for all three sweet orange cultivars. The use of $0.5-$ $2.5 \mathrm{mg} \mathrm{L}^{-1} \mathrm{BAP}$, followed by $1 \mathrm{mg} \mathrm{L}^{-1}$ IBA were the best growth regulator combinations for bud induction and rooting, respectively, for 'Rangpur' lime. The protocols presented in this work are suitable for associations with genetic transformation experiments for these cultivars.
\end{abstract}

Key words: adventitious bud, rooting, genetic transformation

\section{OTIMIZAÇÃO DO PROCESSO DE ORGANOGÊNESE IN VITRO E REGENERAÇÃO DE PLANTAS EM Citrus sinensis E C. limonia}

\begin{abstract}
RESUMO: Com o desenvolvimento de novas técnicas biotecnológicas, é possível a introdução no genoma vegetal de genes de outras plantas ou outros organismos pela transformação genética. Entretanto, um dos principais requisitos para o sucesso desta técnica é a existência de uma metodologia eficiente de regeneração de plantas in vitro. O objetivo deste trabalho foi definir protocolos de regeneração de plantas, via organogênese, para laranjas 'Natal', 'Valência' e 'Hamlin' (Citrus sinensis L. Osbeck), e limão 'Cravo' (Citrus limonia L. Osbeck), para obtenção de plantas transgênicas nestas variedades. Sementes sem tegumentos foram germinadas in vitro durante três semanas no escuro e uma semana sob fotoperíodo de $16 \mathrm{~h}\left(40 \mu \mathrm{mol} \mathrm{m}^{-2} \mathrm{~s}^{-1}\right)$, a $27 \pm 2^{\circ} \mathrm{C}$. Para indução das brotações, segmentos de epicótilo foram cultivados no meio de cultura MT (25 g L $\mathrm{g}^{-1}$ de sacarose) suplementado com diferentes concentrações de benzilaminopurina (BAP). Para enraizamento, utilizou-se meio MT, com ou sem a adição de NAA ou IBA $\left(1,0 \mathrm{mg} \mathrm{L}^{-1}\right)$. A combinação 1,0 $\mathrm{mg} \mathrm{L}^{-1} \mathrm{BAP}$, utilizada na fase de indução de brotações e 1,0 $\mathrm{mg} \mathrm{L}^{-1}$ IBA, utilizada na fase de enraizamento, permitiu regeneração de plantas com bom índice de enraizamento nas três variedades de laranjas. A utilização de $0,5-2,5 \mathrm{mg} \mathrm{L}^{-1}$ BAP na fase de indução de brotações, com $1,0 \mathrm{mg} \mathrm{L}^{-1}$ IBA na fase de enraizamento, assegurou regeneração de plantas com alto índice de enraizamento para o limão 'Cravo'. Os protocolos de organogênese desenvolvidos neste trabalho podem ser utilizados em experimentos de transformação genética envolvendo essas variedades.
\end{abstract}

Palavras-chave: gema adventícia, enraizamento, transformação genética

\section{INTRODUCTION}

With the recent advances of plant biotechnology, it is possible to introduce exogenous genes in the plant genome, using gene transfer techniques. However, for efficient transgenic plant production, a previously defined tissue culture system for better plant regeneration, in association with a genetic transformation system for the gene introduction are necessary (Pérez-Molphe-Balch \& Ochoa-Alejo, 1998).

In citrus, some reports have shown the results of experimentation aiming for the efficient regeneration of plants through organogenesis in vitro, for use with Agrobacterium tumefaciens for genetic transformation. Pérez-Molphe-Balch \& Ochoa-Alejo (1997) studying the effect of BAP and NAA combinations established protocols 
for plant regeneration of Mexican lime (Citrus aurantifolia Christm.) and Monica mandarin (Citrus reticulata Blanco) by direct organogenesis in internodal segments of in vitro germinated plantlets. Ghorbel et al. (1998), using combinations of the same growth regulators, defined protocols for grapefruit (Citrus paradisi Macf.), sour orange (Citrus aurantium L.), and alemow (Citrus macrophylla Wester) by organogenesis, from internodal segments of juvenile plantlets grown in the greenhouse. Recently, Bordón et al. (2000), studying the effect of the cultivars and concentrations of BAP and NAA, established plant regeneration protocols through organogenesis from epicotyl segments of seedlings germinated in vitro for the following rootstocks: sour orange (Citrus aurantium L.), Comuna sweet orange (Citrus sinensis L. Osbeck), Cleopatra mandarin (Citrus reshi Hort. ex Tan.), alemow (Citrus macrophylla Wester), and Troyer citrange (Citrus sinensis L. Osbeck x Poncirus trifoliata L. Raf.).

Citrus genetic transformation has been described for some species and hybrids, such as Carrizo citrange (Moore et al., 1992), Poncirus trifoliata Raf. (Kaneyoshi et al., 1994), Pineapple sweet orange (Peña et al., 1995; Cervera et al., 1998), Washington navel sweet orange (Bond \& Roose, 1998), Mexican lime (Peña et al., 1997; Pérez-Molphe-Balch \& Ochoa-Alejo, 1998), sour orange (Gutiérrez-E et al., 1997), and Duncan grapefruit (Luth \& Moore, 1999). However, many problems are presented, such as low transformation efficiency, difficulties for rooting of transformed plantlets and high number of escapes.

The present work aimed to establish efficient protocols for plant regeneration by organogenesis for three sweet orange varieties Natal, Valencia and Hamlin (Citrus sinensis L. Osbeck) which are important for the Brazilian citrus industry, and for Rangpur lime (Citrus limonia L. Osbeck), the main rootstock used in Brazil. This may be important for the future association with genetic transformation techniques.

\section{MATERIAL AND METHODS}

\section{Plant material and explant preparation}

Seeds were extracted from ripe fruits of Natal, Valencia and Hamlin sweet oranges, and Rangpur lime. Material was collected from a citrus germplasm collection in Piracicaba, SP. Seed teguments were removed and desinfestation was done in a $67 \%$ commercial sodium hypochloride solution ( $2.5 \%$ active chlorine) for 20 minutes. Three washes in distilled and sterilized water were done before the seeds were introduced in test tubes $(150 \times 25$ $\mathrm{mm}$ ) containing $15 \mathrm{~mL}$ of MT medium (Murashige \& Tucker, 1969), supplemented with $25 \mathrm{~g} \mathrm{~L}^{-1}$ sucrose. The seeds were maintained at $27 \pm 2^{\circ} \mathrm{C}$ in the dark for three weeks, followed by one week under a 16-h photoperiod (40 $\mu \mathrm{mol} \mathrm{m} \mathrm{m}^{-2} \mathrm{~s}^{-1}$ ). After this period, epicotyl segment explants (approximately 1.0-cm-long) were excised.
Induction of adventitious buds

Explants of all 4 cultivars were introduced horizontally in Petri dishes $(100 \times 15 \mathrm{~mm})$ containing 20 $\mathrm{mL}$ of MT culture medium solidified with $0.8 \%$ agar and supplemented with $25 \mathrm{~g} \mathrm{~L}^{-1}$ sucrose and different concentrations of benzylaminopurine (BAP): $0.0 ; 0.5 ; 1.0$; $1.5 ; 2.0 ; 2.5 ; 3.0 ; 3.5 ; 4.0$ or $4.5 \mathrm{mg} \mathrm{L}^{-1}$. Cultures were maintained at $27 \pm 2^{\circ} \mathrm{C}$, under 16 -h photoperiod $(40 \mu \mathrm{mol}$ $\mathrm{m}^{-2} \mathrm{~s}^{-1}$ ) for 45 days, when the cultures were evaluated. After evaluation, the adventitious buds were transferred to MT medium with $25 \mathrm{~g} \mathrm{~L}^{-1}$ sucrose, $0.8 \%$ agar and 1.0 $\mathrm{mg} \mathrm{L}^{-1}$ gibberellic acid $\left(\mathrm{GA}_{3}\right)$ for elongation, during 60 days.

A completely randomized factorial was used, with 4 cultivars, 10 BAP concentrations $(4 \times 10)$, and 7 replications. Each replication consisted of one Petri dish, with 8 epicotyl segments each. Percent of explants with adventitious shoots longer than $1.0 \mathrm{~cm}$ (responsive explants) and the number of adventitious shoots longer than $1.0 \mathrm{~cm}$ per responsive explant were evaluated.

\section{Rooting of adventitious shoots}

Culture media with or without auxins were used for rooting of the adventitious shoots. MT medium with $25 \mathrm{~g} \mathrm{~L}^{-1}$ sucrose, $0.8 \%$ agar and $0.5 \mathrm{~g} \mathrm{~L}^{-1}$ activated charcoal was used without auxin, or supplemented with $1.0 \mathrm{mg} \mathrm{L}^{-1}$ indole butyric acid (IBA), or naphthaleneacetic acid (NAA). Cultures were maintained at $16-\mathrm{h}$ photoperiod $\left(40 \mu \mathrm{mol} \mathrm{m} \mathrm{m}^{-2}\right)$ at $27 \pm 2^{\circ} \mathrm{C}$ for 60 days.

The experiment was designed in a $4 \times 10 \times 3$ factorial completely randomized design with 4 cultivars, 10 BAP concentrations and 3 rooting media, with 5 replications, each replication consisting of one flask with 4 shoots. The evaluation was done by the determination of percent of shoots with roots. The data was transformed by $(x+0.5)^{1 / 2}$.

For both experiments (induction of adventitious buds and rooting of adventitious shoots), data were subjected to ANOVA with 5\% significance level. Means were compared by Tukey's multiple range test.

\section{RESULTS AND DISCUSSION}

\section{Induction of adventitious buds}

After a few days in induction medium, many explants showed swelling at the cutting edges, from which adventitious buds developed after the $15^{\text {th }}$ day in culture. Only part of the buds continued to develop to form shoots. Evaluations were done after 45 days in culture, when shoots higher than $1.0 \mathrm{~cm}$ were counted (Figures 1a-c).

The percent of responsive explants showed a significant effect for BAP concentrations and for the interaction BAP $x$ cultivars (Table 1). The results of the effect of BAP concentration isolated showed that 1.0 $\mathrm{mg} \mathrm{L}^{-1} \mathrm{BAP}$ induced the highest percent of explants with adventitious shoots higher than $1.0 \mathrm{~cm}(69.56 \%)$. This was statistically different when compared to the results 
Table 1 - Organogenic response of Citrus epicotyl explants to different concentrations of benzylaminopurine (BAP) in the culture medium (Natal, Valencia, and Hamlin sweet oranges and Rangpur lime).

\begin{tabular}{|c|c|c|c|c|c|c|c|c|c|c|}
\hline \multicolumn{11}{|c|}{ CULTIVAR } \\
\hline \multirow[b]{2}{*}{$\begin{array}{c}\text { Concentration } \\
\text { BAP }\end{array}$} & \multicolumn{2}{|c|}{ Natal } & \multicolumn{2}{|c|}{ Valencia } & \multicolumn{2}{|c|}{ Hamlin } & \multicolumn{2}{|c|}{ Rangpur } & \multicolumn{2}{|c|}{ Mean } \\
\hline & $\begin{array}{c}\text { Responsive } \\
\text { explants }\end{array}$ & $\begin{array}{l}\text { shoots } \\
\text { explant }^{-1}\end{array}$ & $\begin{array}{c}\text { Responsive } \\
\text { explants }\end{array}$ & $\begin{array}{l}\text { shoots } \\
\text { explant }^{-1}\end{array}$ & $\begin{array}{c}\text { Responsive } \\
\text { explants }\end{array}$ & $\begin{array}{l}\text { shoots } \\
\text { explant }^{-1}\end{array}$ & $\begin{array}{c}\text { Responsive } \\
\text { explants }\end{array}$ & $\begin{array}{l}\text { shoots } \\
\text { explant }^{-1}\end{array}$ & $\begin{array}{c}\text { Responsive } \\
\text { explants }\end{array}$ & $\begin{array}{l}\text { shoots } \\
\text { explant }^{-1}\end{array}$ \\
\hline $\mathrm{mg} \mathrm{L}^{-1}$ & $\%$ & $\mathrm{n}^{\circ}$ & $\%$ & $\mathrm{n}^{0}$ & $\%$ & $\mathrm{n}^{\circ}$ & $\%$ & $\mathrm{n}^{\circ}$ & $\%$ & $\mathrm{n}^{\circ}$ \\
\hline 0.0 & $75.0 \mathrm{ab}$ & $1.2 \mathrm{ab}$ & $60.7 \mathrm{ab}$ & $1.1 \mathrm{~b}$ & $71.1 \mathrm{ab}$ & $1.1 \mathrm{~cd}$ & $35.7 \mathrm{a}$ & $1.0 \mathrm{~b}$ & $60.6 \mathrm{ab}$ & $1.1 \mathrm{c}$ \\
\hline 0.5 & $35.7 \mathrm{bc}$ & $1.4 a b$ & $53.6 \mathrm{ab}$ & $1.4 \mathrm{ab}$ & $67.8 \mathrm{abc}$ & $1.6 \mathrm{bc}$ & $39.3 a$ & $1.1 \mathrm{ab}$ & $49.1 \mathrm{ab}$ & $1.4 \mathrm{~b}$ \\
\hline 1.0 & $85.4 \mathrm{a}$ & $1.6 \mathrm{a}$ & $75.0 \mathrm{a}$ & $1.8 \mathrm{a}$ & $71.4 \mathrm{ab}$ & $2.4 \mathrm{a}$ & $46.4 \mathrm{a}$ & $1.1 \mathrm{ab}$ & $69.6 \mathrm{a}$ & $1.7 \mathrm{a}$ \\
\hline 1.5 & $51.8 \mathrm{abc}$ & $1.3 a b$ & $51.8 a b$ & $1.5 a b$ & $64.3 \mathrm{abcd}$ & $1.7 \mathrm{~b}$ & $44.6 \mathrm{a}$ & $1.2 a b$ & $53.1 \mathrm{ab}$ & $1.4 a b$ \\
\hline 2.0 & $42.8 \mathrm{abc}$ & $1.4 \mathrm{ab}$ & $51.8 a b$ & $1.2 \mathrm{ab}$ & $60.7 \mathrm{abcd}$ & $1.6 \mathrm{bcd}$ & $55.3 \mathrm{a}$ & $1.4 a b$ & $52.7 \mathrm{ab}$ & $1.4 \mathrm{~b}$ \\
\hline 2.5 & $57.1 \mathrm{abc}$ & $1.3 a b$ & $41.1 \mathrm{ab}$ & $1.3 a b$ & $48.2 \mathrm{abcd}$ & $1.3 \mathrm{bcd}$ & $50.0 \mathrm{a}$ & $1.5 a b$ & $47.6 \mathrm{ab}$ & $1.3 \mathrm{bc}$ \\
\hline 3.0 & $42.8 \mathrm{abc}$ & $1.2 a b$ & $32.1 \mathrm{ab}$ & $1.1 \mathrm{~b}$ & $46.4 \mathrm{abcd}$ & $1.2 \mathrm{~cd}$ & $60.7 \mathrm{a}$ & $1.6 \mathrm{a}$ & $45.5 \mathrm{bc}$ & $1.3 \mathrm{bc}$ \\
\hline 3.5 & $19.6 \mathrm{c}$ & $1.0 \mathrm{~b}$ & $37.5 a b$ & $1.2 \mathrm{~b}$ & $30.3 \mathrm{bcd}$ & $1.2 \mathrm{~cd}$ & $62.5 \mathrm{a}$ & $1.5 a b$ & $37.5 \mathrm{bc}$ & $1.2 \mathrm{bc}$ \\
\hline 4.0 & $30.3 c$ & $1.0 \mathrm{~b}$ & $23.2 \mathrm{~b}$ & $1.1 \mathrm{~b}$ & $26.8 \mathrm{~cd}$ & $1.1 \mathrm{~d}$ & $33.9 \mathrm{a}$ & $1.1 \mathrm{ab}$ & $28.6 \mathrm{bc}$ & $1.1 \mathrm{c}$ \\
\hline 4.5 & $16.1 \mathrm{c}$ & $1.0 \mathrm{~b}$ & $37.5 \mathrm{~b}$ & $1.0 \mathrm{~b}$ & $23.2 \mathrm{~d}$ & $1.0 \mathrm{~d}$ & $23.2 \mathrm{a}$ & $1.0 \mathrm{~b}$ & $25.0 \mathrm{c}$ & $1.0 \mathrm{c}$ \\
\hline ean & $45.7 \mathrm{~A}$ & $1.2 \mathrm{~B}$ & $46.4 \mathrm{~A}$ & $1.3 \mathrm{~B}$ & $51.0 \mathrm{~A}$ & $1.4 \mathrm{~A}$ & $45.1 \mathrm{~A}$ & $1.3 \mathrm{~B}$ & & \\
\hline
\end{tabular}

Means followed by the same letter do not differ significantly (Tukey, 0.05) (lower-case in columns and upper-case in line).
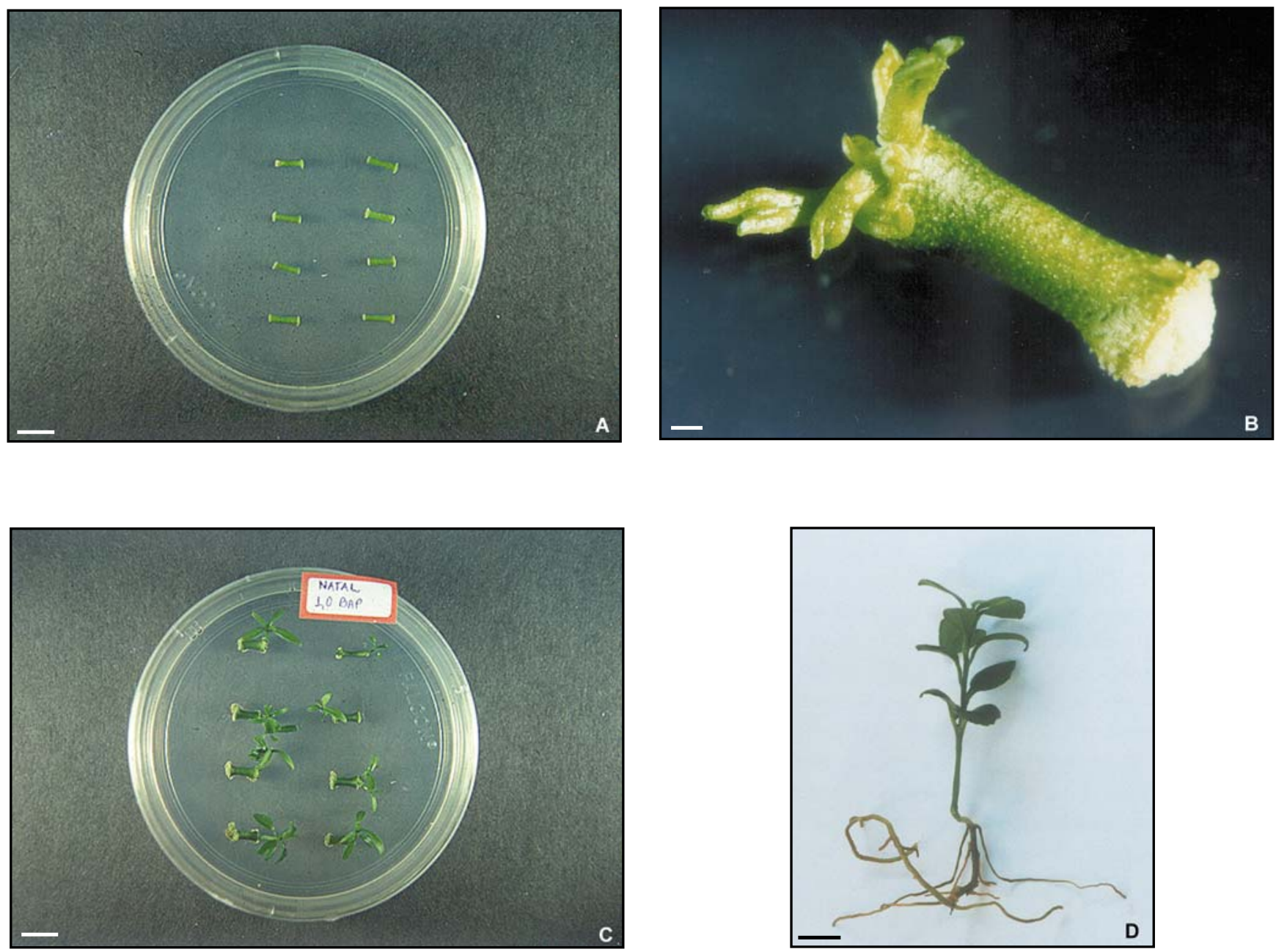

Figure 1 - Adventitious bud formation and rooting of shoot buds obtained from epicotyl segments of citrus. a) explants after five days in culture showing the swollen area at the cutting edges; b) multiple adventitious buds after 15 days in culture; c) shoots ${ }^{3} 1.0 \mathrm{~cm}$ evaluated after 45 days in culture; d) plantlets rooted after 60 days in rooting medium. Bars: $1 \mathrm{~cm}$ (a), (c), (d); 1 mm (b). 
obtained with either $3.0 ; 3.5 ; 4.0$ or $4.5 \mathrm{mg} \mathrm{L}^{-1}$. The analysis of the effect of the interaction (BAP $x$ cultivar) revealed that $1.0 \mathrm{mg} \mathrm{L}^{-1}$ BAP gave the highest percent of responsive explants for Natal, Valencia, and Hamlin sweet oranges, with $85.4 \%, 75 \%$ and $71.42 \%$, respectively, while for Rangpur lime the results were not significantly different among the BAP concentrations tested. Similar results, when comparing different cultivars, were observed by Pérez-Molphe-Balch \& Ochoa-Alejo (1997), with $96 \%$ and $88 \%$ of responsive explants for Mexican lime and mandarin, respectively. The explants used in this case were internodal segments cultured in MS (Murashige \& Skoog, 1962) supplemented with $7.5 \mathrm{mg} \mathrm{L}^{-1}$ BAP and $1.0 \mathrm{mg} \mathrm{L}^{-1} \mathrm{NAA}$.

The analysis of the number of adventitious shoots $(\geq 1.0 \mathrm{~cm})$ obtained per explant showed significant effects of cultivar, BAP concentration and of the interaction (BAP $x$ cultivar), as shown in Table 1. Hamlin sweet orange presented the highest average, with 1.43 shoots explant ${ }^{-1}$ and this results was significantly different from the response observed for the other cultivars, confirming the cultivar-specific characteristic of the organogenic response. Ghorbel et al. (1998) and Bórdon et al. (2000) observed similar results studying several citrus cultivars.

Analyzing the isolated effect of BAP on the number of shoots explant ${ }^{-1}$, it was observed that 1.0 $\mathrm{mg} \mathrm{L}^{-1}$ BAP also showed the best response, with 1.73 shoots explant ${ }^{-1}$. This response significantly differed from the other concentrations, except for $1.5 \mathrm{mg} \mathrm{L}^{-1}$. In addition, BAP concentration above $1.0 \mathrm{mg} \mathrm{L}^{-1}$ caused an antagonic effect, with the higher BAP concentration causing the lowest number of shoots explant ${ }^{-1}$. This trend has also been reported by several authors (Maggon \& Singh, 1995; Pérez-Molphe-Balch \& Ochoa-Alejo, 1997; Ghorbel et al., 1998; Moreira-Dias et al., 2000).

The effect of the interaction BAP $x$ cultivar confirmed that BAP at $1.0 \mathrm{mg} \mathrm{L}^{-1}$ was the best concentration for Natal, Valencia and Hamlin, with averages of $1.59,1.76$ and 2.43 shoots explant ${ }^{-1}$, respectively. For Rangpur lime, $3.0 \mathrm{mg} \mathrm{L}^{-1}$ BAP gave the best result, with 1.57 shoots explant ${ }^{-1}$, being significantly different only from absence of BAP and $4.5 \mathrm{mg} \mathrm{L}^{-1}$ BAP. The average number of shoots explant ${ }^{-1}$ obtained here is lower than the results obtained by Pérez-Molphe-Balch \& Ochoa-Alejo (1997), with 7.8 shoots explant ${ }^{-1}$ for Mexican lime, and 5.1 for mandarin. Ghorbel et al. (1998) obtained 4.1, 2.2 and 9.9 shoots explant ${ }^{-1}$ for grapefruit, sour orange and Citrus macrophylla, respectively. Moreira-Dias et al. (2000) working with Troyer citrange obtained an average of 10.4 shoots explant ${ }^{-1}$, from which only 7.2 developed into plantlets. Each of these authors used a different combination of cultivar, explant type and induction medium, showing that all three parameters can affect the organogenic response. In our experiment, the average of shoots explant ${ }^{-1}$ presented is lower than the results from these reports, which could have been an effect of the cultivars studied. It is important to note, however, that in our analysis we considered only shoots higher than $1.0 \mathrm{~cm}$, while the other authors apparently counted all the visible buds. We observed that although many adventitious buds formed most of the shoots smaller than $1.0 \mathrm{~cm}$ did not develop further.

\section{Rooting of adventitious shoots}

Shoots were considered rooted when a well developed primary root and secondary roots were observed after 60 days in rooting medium (Figure 1d). The analysis of the percent of rooting presented a significant effect among cultivars, BAP concentration used for induction, auxins used for rooting and interaction (BAP $x$ auxin) and (BAP $x$ cultivar). Rangpur lime had the highest percent of rooting, when the isolated effect of cultivar was considered, with an average of $47.22 \%$, which was significantly different from the other cultivars.

The concentration of BAP used in the bud induction medium influenced the percent of rooting, with the best result being observed when $1.0 \mathrm{mg} \mathrm{L}^{-1}$, was used. In this treatment $46.65 \%$ of the shoots were rooted and this results differed significantly from the other treatments, independently of the auxin treatment given for rooting (Table 2). When analyzing the isolated effect of the auxin treatment, IBA conferred the highest rooting average (28\%), differing significantly from the other treatments (Figure 2).

The effect of the interaction BAP concentration $x$ auxin for each cultivar showed that the use of 1.0 $\mathrm{mg} \mathrm{L}^{-1}$ BAP for bud induction, followed by IBA in the rooting stage was the best combination for Natal, Valencia, and Hamlin, with $75 \%, 54 \%$ and $56 \%$ rooting, respectively. For Rangpur lime, however, $0.5 \mathrm{mg} \mathrm{L}^{-1} \mathrm{BAP}$ followed by IBA in the rooting medium resulted in a $94.6 \%$ rooting (Table 2). These results indicate that rooting is also cultivar dependent, as reported by various authors. Edriss \& Burger (1984) obtained $100 \%$ of rooting in shoots from epicotyl segments of Troyer citrange cultivated in $2.0 \mathrm{mg} \mathrm{L}^{-1} \mathrm{NAA}$. Sim et al. (1989) reported $66 \%$ of rooting in shoots of Citrus mitis cultured in medium with $1.0 \mathrm{mg} \mathrm{L}^{-1}$ IBA.

Goh et al. (1995), using the same type of explant cultured in medium with $5.0 \mathrm{mg} \mathrm{L}^{-1}$ IBA, obtained $83 \%$ of rooting in shoots of grapefruit, and the plantlets were successfully acclimatized and transplanted to soil. Ghorbel et al. (1998) compared the effects of NAA in rooting of shoots of grapefruit, sour orange and Citrus macrophylla. Lack of rooting occurred for the first two cultivars, while rooting was obtained for $C$. macrophylla in medium supplemented with $3.0 \mathrm{mg} \mathrm{L}^{-1} \mathrm{NAA}$. Although the rate of rooting was high for this species, these authors report difficulties after transplantation into soil, with only $16 \%$ of survival. As an alternative for these cultivars, these authors suggested the micro-grafting technique, using seedlings as rootstocks. Their results showed 51 and $80 \%$ of success for grapefruit and sour orange, respectively. Due to the qualitative and quantitative response of the morphogenic processes in vitro, Bordón et al. (2000) suggested that plant regeneration in vitro should be optimized for each individual cultivar. 
Table 2 - Response of adventitious shoots of Natal, Valencia, and Hamlin sweet oranges, and Rangpur lime induced in different BAP concentrations and submitted to rooting with or without auxins'1.

\begin{tabular}{|c|c|c|c|c|c|c|c|c|c|c|c|c|c|}
\hline \multicolumn{14}{|c|}{ CULTIVAR } \\
\hline \multirow[b]{2}{*}{$\begin{array}{l}\text { Concentration } \\
\text { BAP bud } \\
\text { induction }\end{array}$} & \multicolumn{3}{|c|}{ Natal } & \multicolumn{3}{|c|}{ Valencia } & \multicolumn{3}{|c|}{ Hamlin } & \multicolumn{3}{|c|}{ Rangpur } & \multirow[t]{2}{*}{ Mean } \\
\hline & $\mathrm{N} / \mathrm{A}^{*}$ & $\mathrm{NAA}^{*}$ & $\mathrm{BBA}^{*}$ & $\mathrm{~N} / \mathrm{A}$ & NAA & $\mathrm{IBA}$ & $\mathrm{N} / \mathrm{A}$ & NAA & IBA & $N / A$ & NAA & IBA & \\
\hline \multicolumn{14}{|c|}{ Percentage of rooting } \\
\hline 0.0 & $41.5 \mathrm{a}$ & $21.6 \mathrm{ab}$ & $39.3 \mathrm{ab}$ & $3.0 \mathrm{a}$ & $6.5 \mathrm{a}$ & $26.0 \mathrm{ab}$ & $40.0 \mathrm{a}$ & $3.0 \mathrm{ab}$ & $52.0 \mathrm{ab}$ & $48.2 \mathrm{ab}$ & $60.3 a$ & $80.4 \mathrm{a}$ & $32.72 a b$ \\
\hline 0.5 & $9.6 \mathrm{a}$ & $30.0 \mathrm{ab}$ & $44.3 \mathrm{a}$ & $3.0 \mathrm{a}$ & $21.6 \mathrm{a}$ & $35.0 \mathrm{ab}$ & $14.4 \mathrm{a}$ & $44.0 \mathrm{a}$ & $52.0 \mathrm{ab}$ & 89.4 a & $77.2 \mathrm{a}$ & $94.6 \mathrm{a}$ & $41.30 \mathrm{ab}$ \\
\hline 1.0 & $29.0 \mathrm{a}$ & $48.2 \mathrm{ab}$ & $75.0 \mathrm{a}$ & $8.7 \mathrm{a}$ & $44.0 \mathrm{a}$ & $54.0 \mathrm{a}$ & $26.0 \mathrm{a}$ & $29.0 \mathrm{ab}$ & $56.0 \mathrm{a}$ & $74.0 \mathrm{ab}$ & $75.0 \mathrm{a}$ & $63.0 \mathrm{a}$ & $46.65 \mathrm{a}$ \\
\hline 1.5 & $53.5 \mathrm{a}$ & $60.0 \mathrm{a}$ & $44.1 \mathrm{a}$ & $11.5 \mathrm{a}$ & $19.0 \mathrm{a}$ & $35.0 \mathrm{ab}$ & $6.5 \mathrm{a}$ & $6.5 \mathrm{ab}$ & $29.0 \mathrm{ab}$ & $29.0 \mathrm{ab}$ & $29.0 \mathrm{a}$ & $63.0 \mathrm{a}$ & $31.02 \mathrm{abc}$ \\
\hline 2.0 & $11.5 \mathrm{a}$ & $20.1 \mathrm{ab}$ & $27.2 \mathrm{ab}$ & $19.0 \mathrm{a}$ & $15.6 \mathrm{a}$ & $39.0 \mathrm{ab}$ & $6.5 \mathrm{a}$ & $6.5 \mathrm{ab}$ & $30.3 \mathrm{ab}$ & $37.0 \mathrm{ab}$ & $77.2 \mathrm{a}$ & $42.0 \mathrm{a}$ & $26.52 b c$ \\
\hline 2.5 & $14.4 \mathrm{a}$ & $24.1 \mathrm{ab}$ & $21.2 \mathrm{ab}$ & $13.3 \mathrm{a}$ & $33.3 \mathrm{a}$ & $23.1 \mathrm{ab}$ & $8.7 \mathrm{a}$ & $14.4 \mathrm{ab}$ & $22.0 \mathrm{ab}$ & $27.2 \mathrm{ab}$ & $57.0 \mathrm{a}$ & $67.2 \mathrm{a}$ & $26.40 \mathrm{bc}$ \\
\hline 3.0 & $17.6 \mathrm{a}$ & $32.0 \mathrm{ab}$ & $27.2 \mathrm{ab}$ & $17.6 \mathrm{a}$ & $14.4 \mathrm{a}$ & $14.4 \mathrm{ab}$ & $6.5 \mathrm{a}$ & $9.6 \mathrm{ab}$ & $22.0 \mathrm{ab}$ & $13.3 \mathrm{~b}$ & $26.0 \mathrm{a}$ & $23.0 \mathrm{a}$ & $18.22 \mathrm{c}$ \\
\hline 3.5 & $53.5 \mathrm{a}$ & $17.0 \mathrm{ab}$ & $11.5 \mathrm{ab}$ & $21.6 a$ & $8.7 \mathrm{a}$ & $3.0 \mathrm{~b}$ & $8.7 \mathrm{a}$ & $3.0 \mathrm{ab}$ & $3.0 \mathrm{~b}$ & $58.0 \mathrm{ab}$ & $27.0 \mathrm{a}$ & $23.0 \mathrm{a}$ & $18.12 \mathrm{c}$ \\
\hline 4.0 & $3.0 \mathrm{a}$ & $6.5 \mathrm{ab}$ & $6.5 \mathrm{ab}$ & $13.3 \mathrm{a}$ & $8.7 \mathrm{a}$ & $6.5 \mathrm{ab}$ & $3.0 \mathrm{a}$ & $1.0 \mathrm{~b}$ & $3.0 \mathrm{~b}$ & $30.0 \mathrm{ab}$ & $24.0 \mathrm{a}$ & $24.0 \mathrm{a}$ & $10.70 \mathrm{c}$ \\
\hline 4.5 & $3.0 \mathrm{a}$ & $3.0 \mathrm{~b}$ & $1.0 \mathrm{~b}$ & $6.5 \mathrm{a}$ & $8.7 \mathrm{a}$ & $3.0 \mathrm{~b}$ & $3.0 \mathrm{a}$ & $1.0 \mathrm{~b}$ & $3.0 \mathrm{~b}$ & $56.0 \mathrm{ab}$ & $29.0 \mathrm{a}$ & $17.6 \mathrm{a}$ & $10.60 \mathrm{c}$ \\
\hline \multicolumn{2}{|c|}{ Mean by Cultivar } & $25.65 \mathrm{~B}$ & & & $16.5 \mathrm{C}$ & & & $15.55 \mathrm{C}$ & & & $47.22 \mathrm{~A}$ & & \\
\hline
\end{tabular}

${ }^{1}$ The original data was transformed using $(x+0.5)^{1 / 2}$

${ }^{*} \mathrm{~N} / \mathrm{A}=$ absence of auxin; NAA and IBA at $1.0 \mathrm{mg} \mathrm{L}^{-1}$

Means followed by the same letter do not differ significantly (Tukey, 0.05) (lower-case in columns and upper-case in line).

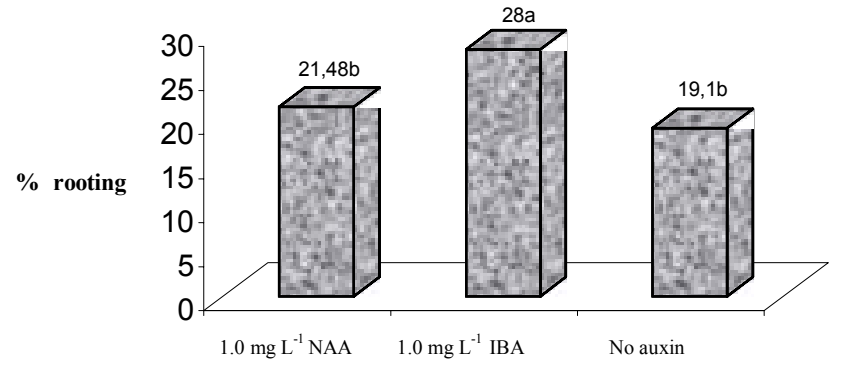

Figure 2 - Auxin sources and rooting of adventitious shoots of sweet oranges 'Natal', 'Valência' and 'Hamlin' and 'Rangpur' lime. Bars with the same letter do not differ significantly (Tukey, 0.05).

The results obtained in this report showed differences in response when three sweet orange varieties and Rangpur lime were compared. The combination of $1.0 \mathrm{mg} \mathrm{L}^{-1}$ BAP for adventitious bud induction in epicotyl segments, followed by rooting in medium with $1.0 \mathrm{mg} \mathrm{L}^{-1}$ IBA gave good rooting percentage for Natal, Valencia, and Hamlin sweet oranges. Rangpur lime explants, however, presented better results when cultured in medium with $0.5-2.5 \mathrm{mg}$ $\mathrm{L}^{-1} \mathrm{BAP}$ for adventitious bud induction and rooting of shoots in medium supplemented with $1.0 \mathrm{mg} \mathrm{L}^{-1}$ IBA. The organogenesis protocols presented here will be further used in experiments of genetic transformation of the cultivars studied.

\section{ACKNOWLEDGEMENTS}

To FAPESP and Fundecitrus for financial support.

\section{REFERENCES}

BOND, J.E.; ROOSE, M.L. Agrobacterium-mediated transformation of the commercially important citrus cultivar Washington navel orange. Plant Cell Reports, v.18, p.229234, 1998.

BORDÓN, Y.; GUARDIOLA, J.L.; GARCIA-LUIS, A. Genotype affects the morphogenic response in vitro of epicotyl segments of Citrus rootstocks. Annals of Botany, v.86, p.159-166, 2000.

CERVERA, M.; JUÁREZ, J.; NAVARRO, A.; PINA, J.A.; DURANVILA, N.; NAVARRO, L.; PEÑA, L. Genetic transformation and regeneration of mature tissue of woody fruit plants bypassing the juvenile stage. Transgenic Research, v.7, p.51-59, 1998.

EDRISS, M.H.; BURGER, D.W. In vitro propagation of 'Troyer' citrange from epicotyl segments. Scientia Horticulturae, v.23, p.159-162, 1984.

GHORBEL, B.R.; NAVARRO, L.; DURAN-VILA, N. Morphogenesis and regeneration of whole plants of grapefruit (Citrus paradisi), sour orange (C. aurantium) and alemow (C. macrophylla). Journal of Horticultural Science and Biotechnology, v.73, p.323-327, 1998.

GOH, C.J.; SIM, G.E.; MORALES, C.L.; LOH, C.S. Plantlet regeneration through different morphogenic pathways in pummelo tissue culture. Plant Cell, Tissue and Organ Culture, v.43, p.301-303, 1995.

GUTIÉRREZ-E, M.A.; LUTH, D.; MOORE, G.A. Factors affecting Agrobacterium-mediated transformation in Citrus and production of sour orange (Citrus aurantium) plants expressing the coat protein gene of citrus tristeza virus. Plant Cell Reports, v.16, p.745-753, 1997.

KANEYOSHI, J.; KOBAYASHI, S.; NAKAMURA, Y. A simple and efficient gene transfer system of trifoliate orange. Plant Cell Reports, v.13, p.541-545, 1994.

LUTH, D.; MOORE, G. Transgenic grapefruit plants obtained by Agrobacterium tumefaciens-mediated transformation. Plant Cell, Tissue and Organ Culture, v.57, p.219-222, 1999.

MAGGON, R.; SINGH, B.D. Promotion of adventitious bud regeneration by ABA in combination with BAP in epicotyl and hypocotyl explants of sweet orange (Citrus sinensis L. Osbeck). Scientia Horticulturae, v.63, p.123-128, 1995. 
MOORE, G.A.; JACANO, C.C.; NEIDIGH, J.L. Agrobacteriummediated transformation of citrus stem segments and regeneration of transgenic plants. Plant Cell Reports, v.11, p.238-242, 1992.

MOREIRA-DIAS, J.M.; MOLINA, R.V.; BORDÓN, Y.; GUARDIOLA, J.L.; GARCÍA-LUIS, A. Direct and indirect shoot organogenic pathways in epicotyl cuttings of Troyer citrange differ in hormone requirements and their response to light. Annals of Botany, v.85, p.103-110, 2000.

MURASHIGE, T.; SKOOG, F. A revised medium for rapid growth and bioassays with tobacco tissue culture. Physiologia Plantarum, v.15, p.473-497, 1962.

MURASHIGE, T.; TUCKER, D.P.H. Growth factor requirement of citrus tissue culture. In: INTERNACIONAL CITRUS SYMPOSIUM, 1., Riverside, 1969. Proceedings. Riverside: University of California, 1969. v.3, p.1155-1169.

PEÑA, L.; CERVERA, M.; JUAREZ, J.; NAVARRO, A.; PINA, J.A.; DURÁN-VILA, N.; NAVARRO, L. Agrobacteriummediated transformation of sweet orange and regeneration of transgenic plants. Plant Cell Reports, v.14, p.616-619, 1995.
PEÑA, L.; CERVERA, M.; JUÁREZ, J.; NAVARRO, A.; PINA, J.A.; NAVARRO, L. Genetic transformation of lime (Citrus aurantifolia): factors affecting transformation and regeneration. Plant Cell Reports, v.16, p.731-737, 1997.

PÉREZ-MOLPHE-BALCH, E.; OCHOA-ALEJO, N. In vitro plant regeneration of mexican lime and mandarin by direct organogenesis. HortScience, v.32, p.931-934, 1997.

PÉREZ-MOLPHE-BALCH, E.; OCHOA-ALEJO, N. Regeneration of transgenic plants of Mexican lime from Agrobacterium rhizogenes-transformed tissues. Plant Cell Reports, v.17, p.591-596, 1998.

SIM, G.E.; GOH, C.J.; LOH, C.S. Micropropagation of Citrus mitis Blanco: multiple bud formation from shoot and root explants in the presence of 6-benzylaminopurine. Plant Science, v.59, p.203-210, 1989.

Received August 01, 2001 